\title{
Evaluation of Antifungal Activity and Mode of Action of New Coumarin Derivative, 7-Hydroxy-6-nitro-2H-1-benzopyran-2-one, against Aspergillus spp.
}

\author{
Felipe Queiroga Sarmento Guerra, ${ }^{1}$ Rodrigo Santos Aquino de Araújo, ${ }^{2}$ \\ Janiere Pereira de Sousa, ${ }^{1}$ Fillipe de Oliveira Pereira, ${ }^{3}$ Francisco J. B. Mendonça-Junior, ${ }^{2}$ \\ José M. Barbosa-Filho, ${ }^{2}$ and Edeltrudes de Oliveira Lima ${ }^{1}$ \\ ${ }^{1}$ Pharmaceutical Science Department, Federal University of Paraíba, 58051-970 João Pessoa, PB, Brazil \\ ${ }^{2}$ Laboratory of Synthesis and Drug Delivery, Biological Science Department, State University of Paraíba, \\ 58020-540 João Pessoa, PB, Brazil \\ ${ }^{3}$ Center of Education and Heath, Federal University of Campina Grande, 58175-000 Cuité, PB, Brazil
}

Correspondence should be addressed to Felipe Queiroga Sarmento Guerra; felipeqsguerra@gmail.com

Received 2 April 2015; Revised 26 May 2015; Accepted 28 May 2015

Academic Editor: Filippo Maggi

Copyright (C) 2015 Felipe Queiroga Sarmento Guerra et al. This is an open access article distributed under the Creative Commons Attribution License, which permits unrestricted use, distribution, and reproduction in any medium, provided the original work is properly cited.

\begin{abstract}
Aspergillus spp. produce a wide variety of diseases. For the treatment of such infections, the azoles and Amphotericin B are used in various formulations. The treatment of fungal diseases is often ineffective, because of increases in azole resistance and their several associated adverse effects. To overcome these problems, natural products and their derivatives are interesting alternatives. The aim of this study was to examine the effects of coumarin derivative, 7-hydroxy-6-nitro-2H-1-benzopyran-2-one $\left(\mathrm{Cou}^{-} \mathrm{NO}_{2}\right)$, both alone and with antifungal drugs. Its mode of action against Aspergillus spp. Cou- $\mathrm{NO}_{2}$ was tested to evaluate its effects on mycelia growth and germination of fungal conidia of Aspergillus spp. We also investigated possible Cou- $\mathrm{NO}_{2}$ action on cell walls ( $0.8 \mathrm{M}$ sorbitol) and on Cou- $\mathrm{NO}_{2}$ to ergosterol binding in the cell membrane. The study shows that Cou- $\mathrm{NO}_{2}$ is capable of inhibiting both the mycelia growth and germination of conidia for the species tested, and that its action affects the structure of the fungal cell wall. At subinhibitory concentration, Cou- $\mathrm{NO}_{2}$ enhanced the in vitro effects of azoles. Moreover, in combination with azoles (voriconazole and itraconazole) Cou- $\mathrm{NO}_{2}$ displays an additive effect. Thus, our study supports the use of coumarin derivative 7-hydroxy-6-nitro2H-1-benzopyran-2-one as an antifungal agent against Aspergillus species.
\end{abstract}

\section{Introduction}

The incidence and prevalence of invasive fungal infections have increased in recent years, especially in the currently large population of immunocompromised patients and those hospitalized with serious underlying diseases. Fungal species represent $25 \%$ of the microorganisms isolated in blood cultures of hospitalized patients. Of these, species of the genus Aspergillus spp. have the highest incidence among the filamentous fungi $[1,2]$.
Aspergillus spp. produce a wide variety of diseases. The main route of infection is penetration by air. In cases of invasive aspergillosis Aspergillus fumigatus is the most common species isolated in the world. In Brazil, the species A. flavus is the most common [3]. The main clinical manifestations observed due to Aspergillus spp. infections are cutaneous aspergillosis, otomycosis, aspergilloma, and sinusitis [4].

For the treatment of such infections, the azoles (Fluconazole, Itraconazole, and Voriconazole) and Amphotericin $\mathrm{B}$ are used in various formulations. However, with the 


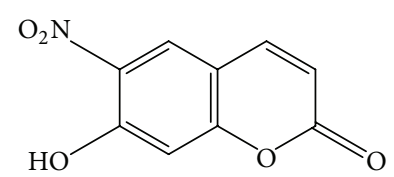

Figure 1: Chemical structure for 7-hydroxy-6-nitro-2H-1-benzopyran-2-one $\left(\mathrm{Cou}-\mathrm{NO}_{2}\right)$.

increase of azole resistance, and the several adverse effects associated with the use of Amphotericin B (which include nephrotoxicity and neurotoxicity [5]), the treatment of fungal diseases is often ineffective, which has caused alarm among health professionals.

To overcome these problems, natural products and their derivatives are interesting alternatives. The coumarins (phenolic compounds which possess a benzopyranone nucleus and are one of the major classes of secondary metabolites) have been highlighted in antimicrobial activity studies [6-8].

Recently reported by our group, the antifungal activity against Aspergillus fumigatus and A. flavus of twentyfour coumarin derivatives was described. Some of these derivatives showed significant antifungal activity with Minimum Inhibition Concentration (MIC) values ranging from 16 to $32 \mu \mathrm{g} / \mathrm{mL}$. 7-hydroxy-6-nitro-2H-1-benzopyran-2-one (Figure 1) revealed an MIC value of $16 \mu \mathrm{g} / \mathrm{mL}$ [9]. Despite the promising results of the study, a need remains for better assessment of the effects of coumarin derivatives on the fungus structure and possible mechanisms action.

Increases in the availability of antifungal compounds have induced searches for better therapeutic strategies, such as the use of two or more antifungal drugs in combination [10]. Combination therapy of antifungal drugs with natural products and their derivatives has been little explored; this is especially true for the coumarin derivatives, which promise an alternative against strains of Aspergillus spp.

The aim of this study was to examine the effects and mode of action of coumarin derivative, 7-hydroxy-6-nitro-2H-1benzopyran-2-one, both alone and together with antifungal drugs, against Aspergillus spp.

\section{Material and Methods}

2.1. Microorganisms. Aspergillus spp. used in the antifungal assay were obtained from the archival collection of the Federal University of Paraíba Laboratory of Mycology (LM). They included A. fumigatus (ATCC 46913, LM 121, LM 743, and LM 135) and A. flavus (ATCC 16013, LM 35, LM 36, and LM 23). Stock inoculators (suspensions) of Aspergillus spp. were prepared from 8-day old potato dextrose agar (Difco Lab., USA), the cultures grown at room temperature. Fungal colonies were covered with $5 \mathrm{~mL}$ of sterile saline solution $(0,9 \%)$, the surface was gently agitated with vortexes, and fungal elements with saline solution were transferred to sterile tubes. Inoculator was standardized at 0.5 tube of McFarland scale $\left(10^{6} \mathrm{CFU} / \mathrm{mL}\right)$. The final concentration confirmation was done by counting the microorganisms in a Neubauer chamber [11-13].
2.2. Chemicals. The product tested was the coumarin derivative, 7-hydroxy-6-nitro-2H-1-benzopyran-2-one (Cou- $\left.\mathrm{NO}_{2}\right)$, obtained by biosynthesis [9]. Amphotericin B, Fluconazole, Itraconazole, and Voriconazole were obtained from Sigma Aldrich, Brazil. The drugs were dissolved in DMSO (dimethylsulfoxide), and sterile distilled water was used to obtain solutions of $1024 \mu \mathrm{g} / \mathrm{mL}$ for each antifungals. The concentration of DMSO did not exceed $0.5 \%$ in the assays.

2.3. Culture Media. To test the biological activity of the products, Potato Agar (AP) and Sabouraud dextrose agar (SDA) were purchased from Difco Laboratories (Detroit, MI, USA), and RPMI-1640-L-glutamine (without sodium bicarbonate) (Sigma-Aldrich, São Paulo, SP, Brazil) culture media were used. They were prepared and used according to the manufacturers' instructions.

2.4. Minimum Inhibitory Concentration (MIC). The determination of minimum inhibitory concentration against ATCC strains was demonstrated in an article previously published by our group [9]. We also carried out determinations of the coumarin derivative CIM in clinical strains of $A$. flavus and A. fumigatus. Broth microdilution assays were used to determine the MICs of coumarin derivative 7-hydroxy6-nitro-2H-1-benzopyran-2-one $\left(\mathrm{Cou}-\mathrm{NO}_{2}\right)$, and Amphotericin B. RPMI-1640 was added to all the wells of 96well plates. Twofold serial dilutions of the three agents were prepared to obtain concentrations varying between $4 \mu \mathrm{g} / \mathrm{mL}$ and $1024 \mu \mathrm{g} / \mathrm{mL}$. Finally, $10 \mu \mathrm{L}$ aliquots of the inoculate suspension were added to the wells, and the plates were incubated at $28^{\circ} \mathrm{C}$ for 3 days. Negative controls (without drugs) were used to confirm conidia viability, and sensitivity controls (for DMSO) were also included in the studies. At $72 \mathrm{~h}$ there were visual observations for fungal growth. The MIC was defined as the lowest concentration capable of visually inhibiting fungal growth by $100 \%$. The results were expressed as the arithmetic mean of three experiments $[14,15]$.

2.5. Effects on Mycelia Growth. Analysis of the interference of coumarin derivative, 7-hydroxy-6-nitro-2H-1-benzopyran-2one, on mycelia growth was performed by determining the dry mycelia weight of A. fumigatus (ATCC 46913) and A. flavus (ATCC 16013) [15, 16]. Flasks containing MIC $(16 \mu \mathrm{g} / \mathrm{mL})$ and $\mathrm{MIC} \times 2(32 \mu \mathrm{g} / \mathrm{mL})$ of coumarin derivative in RPMI-1640 medium were inoculated with suspension of the test A. fumigatus (ATCC 46913) and A. flavus (ATCC 16013) strains. In the corresponding control, the same amount of coumarin derivative was replaced by distilled water. The system was incubated at $28^{\circ} \mathrm{C}$ for 8 days. Flasks containing mycelia were filtered through Whatman Grade 1 Qualitative Filtration Paper (particle retention: $11 \mu \mathrm{m}$ ) and then washed with distilled water. The mycelia were dried at $60^{\circ} \mathrm{C}$ for $6 \mathrm{~h}$ and kept at $40^{\circ} \mathrm{C}$ overnight. The filter paper containing dry mycelia from two independent assays was weighed, and the mean values were obtained. Percentage growth inhibition based on the dry weight of each at time of analysis was calculated according to Sharma and Tripathi [15]. 
2.6. Conidial Germination Assay. The coumarin derivative, 7-hydroxy-6-nitro-2H-1-benzopyran-2-one $\left(\mathrm{Cou}-\mathrm{NO}_{2}\right)$, and Amphotericin B were tested to evaluate effects on the germination of fungal conidia of A. fumigatus (ATCC 46913) and A. flavus (ATCC 16013). Flasks containing MIC $(16 \mu \mathrm{g} / \mathrm{mL})$ and MIC $\times 2(32 \mu \mathrm{g} / \mathrm{mL})$ of coumarin derivative and a control with distilled water were used. In sterile test tubes, $500 \mu \mathrm{L}$ of RPMI-1640 plus the Cou- $\mathrm{NO}_{2}$ were evenly mixed with $500 \mu \mathrm{L}$ of fungal conidia suspension and immediately incubated at $28^{\circ} \mathrm{C}$. Samples of this mixture were taken after $24 \mathrm{~h}$ of incubation for analysis. The whole experiment was performed in duplicate, where the number of conidia was determined in a Neubauer chamber, and the inhibition percentage of spore germination at each time point was calculated by comparing the results obtained in the test experiments with the results of the control experiment. The analysis was conducted under an optical microscope (Zeiss Primo Star) $[17,18]$.

2.7. Sorbitol Assay Effects. The assay was performed using medium with and without sorbitol (control), to evaluate possible mechanisms involved in the antifungal activity of the test product on the Aspergillus spp. cell wall. The sorbitol was added to the culture medium in a final concentration of $0.8 \mathrm{M}$. The assay was performed by microdilution method in 96-well plates in a "U” (Alamar, Diadema, SP, Brazil) $[11,12]$. The plates were sealed aseptically, incubated at $28^{\circ} \mathrm{C}$, and readings were taken at 3 days. Based on the ability of sorbitol to act as a fungal cell wall osmotic protective agent, the higher MIC values observed in the medium with added sorbitol compared to the standard medium suggest the cell wall as one of the possible cell targets for the product tested [19-21]. Amphotericin B was used as the control drug. The assay was performed in duplicate and expressed as the geometric mean of the results.

2.8. Ergosterol Binding Assay: MIC Value Determination in Presence of Ergosterol. To assess if the product binds to the fungal membrane sterols, an experiment was performed according to the method described by Escalante et al. [22], with some modifications. The ergosterol was prepared as was described by Leite et al. [21]. The MIC of coumarin derivative, 7-hydroxy-6-nitro-2H-1-benzopyran-2-one (Cou$\mathrm{NO}_{2}$ ), against Aspergillus spp. was determined by using broth microdilution techniques $[11,12]$, in the presence and absence of exogenous ergosterol (Sigma-Aldrich, São Paulo, SP, Brazil) added to the assay medium, in different lines of the same microplate. Briefly, a solution of Cou- $\mathrm{NO}_{2}$ was doubly diluted serially with RPMI-1640 (volume $=100 \mu \mathrm{L}$ ) containing plus ergosterol at a concentration of $400 \mu \mathrm{g} / \mathrm{mL}$. A volume of $10 \mu \mathrm{L}$ yeast suspension (0,5 McFarland) was added to each well. The same procedure was realized for Amphotericin $\mathrm{B}$, whose interaction with membrane ergosterol is already known, serving as a control drug. The plates were sealed and incubated at $28^{\circ} \mathrm{C}$. The plates were read after 3 days of incubation, and the MIC was determined as the lowest concentration of test agent inhibiting the visible growth. The assay was carried out in duplicate and the geometric mean values were calculated. Thus, this binding assay reflected the ability of the compound to bind with ergosterol.

2.9. Checkerboard Assay. A checkerboard microtiter test was performed to evaluate the interaction of coumarin derivative, 7-hydroxy-6-nitro-2H-1-benzopyran-2-one, with the antifungal drugs (azoles and Amphotericin B) against A. fumigatus, ATCC 46913, and A. flavus, ATCC 16013. A series of 2-fold dilutions, in eight for each coumarin derivative and antifungal drug, were made in RPMI-1640 to obtain four times the final concentration being achieved in the microtiter well. Furthermore, $50 \mu \mathrm{L}$ of each dilution of coumarin derivative was added to the 96-well microtiter plates in the vertical direction, while $50 \mu \mathrm{L}$ of each dilution of antifungal drugs was added in the horizontal direction, so that various combinations of coumarin derivative and antifungal drugs could be achieved. In addition, $10 \mu \mathrm{L}$ of inoculum from the spore suspension $\left(1.5 \times 10^{5} \mathrm{CFU} \mathrm{mL}^{-1}\right)$ was added to each well, and the plates were incubated at $30^{\circ} \mathrm{C}$ for 3 days.

In order to evaluate the activity of the combinations of drugs, fractional inhibitory concentration (FIC) indices were calculated as $\mathrm{FIC}^{\mathrm{A}}+\mathrm{FIC}^{\mathrm{B}}$, where $\mathrm{FIC}^{\mathrm{A}}$ and FIC $^{B}$ represent the minimum concentrations inhibiting the fungal growth for drugs $\mathrm{A}$ and $\mathrm{B}$, respectively: $\mathrm{FIC}^{\mathrm{A}}=\mathrm{MIC}^{\mathrm{A}}$ combination $/ \mathrm{MIC}^{\mathrm{A}}$ alone and $\mathrm{FIC}^{\mathrm{B}}=\mathrm{MIC}^{\mathrm{B}}$ combination/ $\mathrm{MIC}^{\mathrm{B}}$ alone. A mean FIC index was calculated based on the following equation: FIC index $=\mathrm{FIC}^{\mathrm{A}}+\mathrm{FIC}^{\mathrm{B}}$.

In addition, the interpretation was made as follows: synergistic $(<0.5)$, additivity $(0.5-1.0)$, indifferent $(>1)$, or antagonistic $(>4)[23,24]$.

2.10. Drug Susceptibility Test. The minimum inhibitory concentrations (MIC) of coumarin derivative, 7-hydroxy-6nitro-2H-1-benzopyran-2-one $\left(\mathrm{Cou}-\mathrm{NO}_{2}\right)$, and antifungal drug were determined in RPMI-1640 by microdilution assay using spore suspension $\left(1.5 \times 10^{5} \mathrm{CFU} \mathrm{mL}^{-1}\right)$ and a drug concentration range of 1024 to $2,5 \mu \mathrm{g} / \mathrm{mL}$ (twofold serial dilutions) [24]. MIC was defined as the lowest concentration at which no growth was observed. For the evaluation of the coumarin derivative as a modulator of antifungal properties, MICs of the antifungal drugs were determined in the presence of Cou- $\mathrm{NO}_{2}(2 \mu \mathrm{g} / \mathrm{mL})$ and at subinhibitory concentrations (MIC/8); the plates were incubated for 3 days at $30^{\circ} \mathrm{C}[25]$.

2.11. Data Analysis. The results were expressed in mean \pm SE. Statistical analyses were performed with $t$-test. $P<0.05$ was considered significant.

\section{Results and Discussion}

The difficulty in treating infections caused by Aspergillus spp. is in part related to the rather small arsenal of antifungal agents currently in use. The secondary metabolites derived from plants or biosynthesis serve as important fields of research for new antifungal agents. The coumarin derivative, 7-hydroxy-6-nitro-2H-1-benzopyran-2-one $\left(\mathrm{Cou}-\mathrm{NO}_{2}\right)$, 


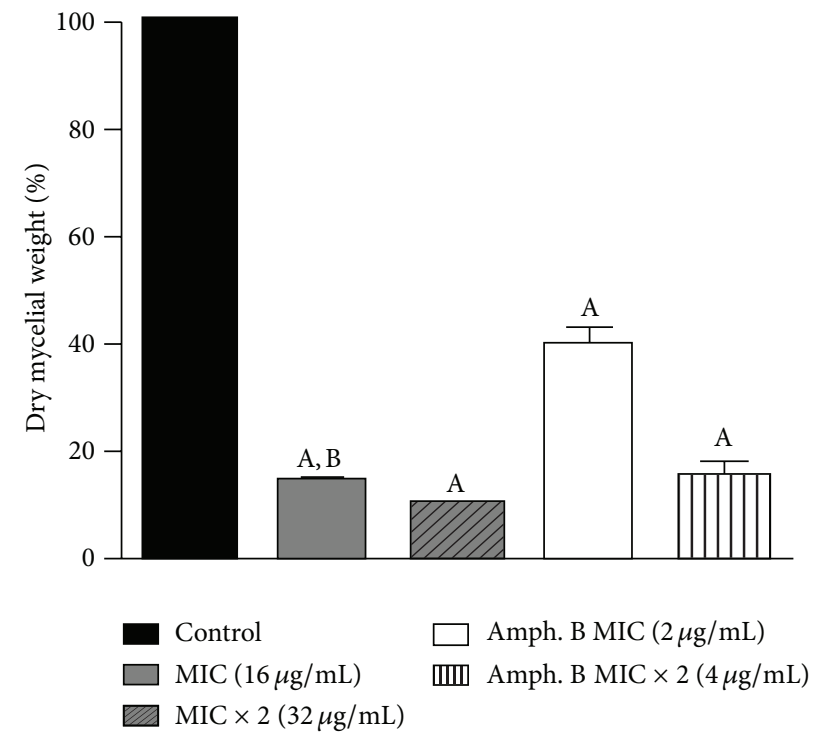

(a)

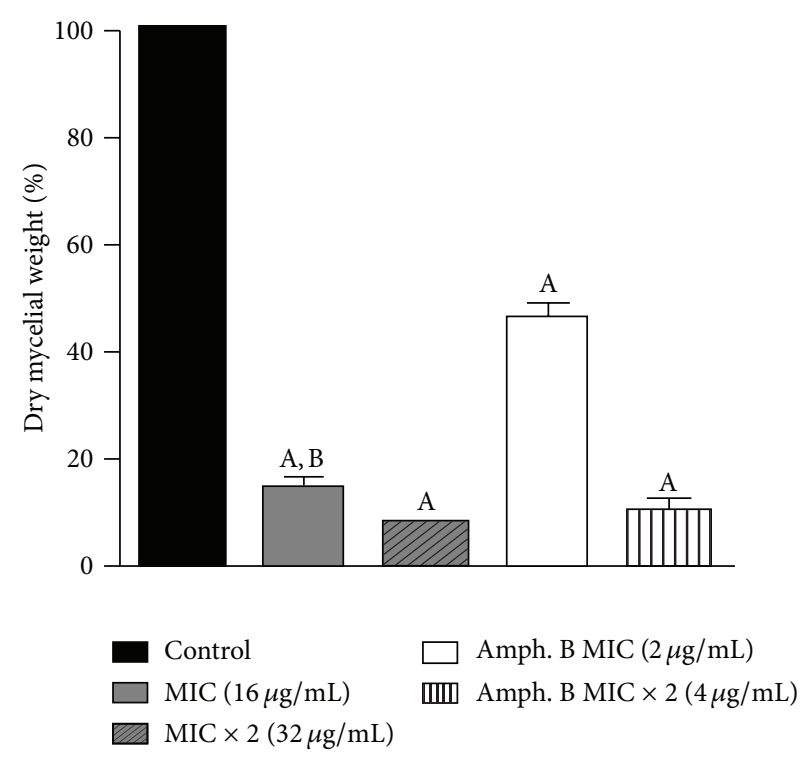

(b)

Figure 2: Percentage of dry mycelia weight produced by A. fumigatus (ATCC 46913) (a) and A. flavus (ATCC 16013) (b) in the absence (control) and presence of 7-hydroxy-6-nitro-2H-1-benzopyran-2-one (MIC: $16 \mu \mathrm{g} / \mathrm{mL}$; MIC $\times 2: 32 \mu \mathrm{g} / \mathrm{mL}$ ) and Amphotericin B (MIC: $2 \mu \mathrm{g} / \mathrm{mL}$; MIC $\times 2: 4 \mu \mathrm{g} / \mathrm{mL}$ ). Control produced $100 \%$ of dry mycelia weight. A: $P<0.05$ compared to control. B: $P<0.05$ compared to Amphotericin B with respective concentration.

TABLE 1: MIC values ( $\mu \mathrm{g} / \mathrm{mL})$ of 7-hydroxy-6-nitro-2H-1-benzopyran-2-one against clinical strains of Aspergillus spp.

\begin{tabular}{|c|c|c|c|c|c|c|}
\hline \multirow[b]{2}{*}{ Microorganisms } & \multicolumn{6}{|c|}{ MIC values $(\mu \mathrm{g} / \mathrm{mL})$} \\
\hline & $\begin{array}{l}\text { A. fumigatus } \\
\text { (LM 121) }\end{array}$ & $\begin{array}{l}\text { A. fumigatus } \\
\text { (LM 135) }\end{array}$ & $\begin{array}{l}\text { A. fumigatus } \\
\text { (LM 743) }\end{array}$ & $\begin{array}{l}\text { A. flavus } \\
\text { (LM 35) }\end{array}$ & $\begin{array}{l}\text { A. flavus } \\
\text { (LM 36) }\end{array}$ & $\begin{array}{l}\text { A. flavus } \\
\text { (LM 23) }\end{array}$ \\
\hline Cou-UNO 2 & 16 & 32 & 32 & 16 & 16 & 16 \\
\hline Amphotericin B & 2 & 2 & 2 & 2 & 2 & 2 \\
\hline Viability control & + & + & + & + & + & + \\
\hline Negative control & - & - & - & - & - & - \\
\hline Sensitivity control & + & + & + & + & + & + \\
\hline
\end{tabular}

Note. Cou- $\mathrm{UNO}_{2}$ : 7-hydroxy-6-nitro-2H-1-benzopyran-2-one.

a biosynthetic compound, has been reported for its antifungal activity [9].

The minimum inhibitory concentration of the coumarin derivative $\left(\mathrm{Cou}-\mathrm{NO}_{2}\right)$ on the clinical strains was similar to that observed previously by our [9] group, however now achieving an MIC of $32 \mathrm{mg} / \mathrm{mL}$ against the clinical strains $A$. fumigatus LM 743 and LM 135 (Table 1).

This study also verified $\mathrm{Cou}-\mathrm{NO}_{2}$ action against Aspergillus mycelial growth and spore germination ( $A$. fumigatus ATCC 46913 and A. flavus ATCC 16013).

The effect of differing concentrations of the test drug $(\mathrm{MIC}$ and MIC $\times 2)$ on mycelia growth was determined by measurement of mycelium dry weights, and the results are shown in Figure 2. With respect to effects on A. fumigatus ATCC 46913 and A. flavus ATCC 16013, it can be seen that Cou- $\mathrm{NO}_{2}$ in MIC concentrations of $(16 \mu \mathrm{g} / \mathrm{mL})$ and MIC $\times 2(32 \mu \mathrm{g} / \mathrm{mL})$ inhibited normal mycelia growth $(P<$ $0.05)$ when compared to the control. The results show that Cou- $\mathrm{NO}_{2}$ at its MIC concentration was more potent than
Amphotericin B at its respective MIC concentration $(P<$ 0.05).

The production of hyphae and consequent mycelium formation are important virulence factors for Aspergillus spp.; Hyphae are more difficult to phagocytize and can induce apoptosis in macrophages, since they often form inside these cells after phagocytosis [26]. Thus, reductions in mycelia growth as an effect of the Cou- $\mathrm{NO}_{2}$ coumarin derivative interfering with the fungal virulence of Aspergillus spp. proved superior to Amphotericin B in its respective MIC concentrations.

Aspergillus spp. produce numerous asexual conidia which are spread throughout the environment and are also considered an important factor in triggering infections in the host. Thus, it is deemed important to quantitatively evaluate the power of a product to interfere with fungal spore germination [26].

The conidial percentage of A. fumigatus ATCC 46913 and A. flavus ATCC 16013 germinated in the presence and absence 


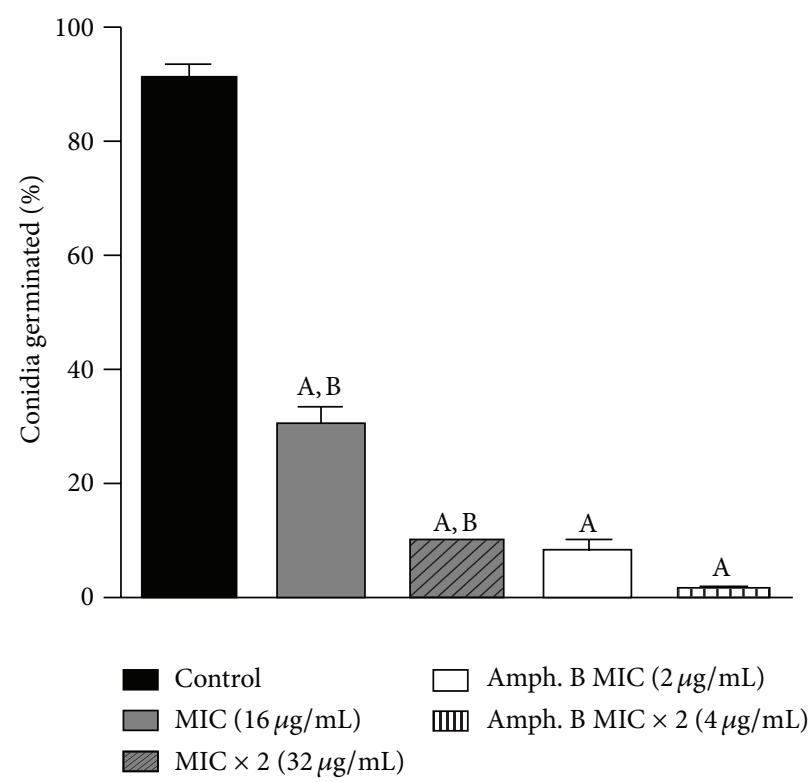

(a)

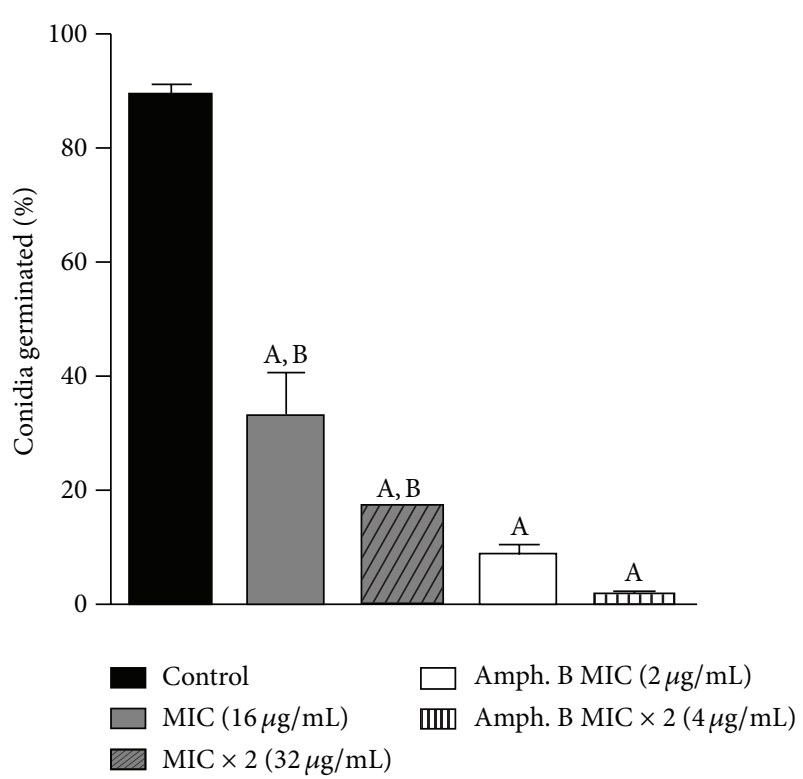

(b)

Figure 3: Percentage of conidial germination of A. fumigatus (ATCC 46913) (a) and A. flavus (ATCC 16013) (b) in the absence (control) and presence of 7-hydroxy-6-nitro-2H-1-benzopyran-2-one (MIC: $16 \mu \mathrm{g} / \mathrm{mL}$; MIC $\times 2: 32 \mu \mathrm{g} / \mathrm{mL}$ ) and Amphotericin B (MIC: $2 \mu \mathrm{g} / \mathrm{mL}$; MIC $\times 2$ : $4 \mu \mathrm{g} / \mathrm{mL}$ ). A: $P<0.05$ compared to control. B: $P<0.05$ compared to Amphotericin B with respective concentration.

TABLE 2: MIC values $(\mu \mathrm{g} / \mathrm{mL})$ of drugs in the absence and presence of sorbitol $(0.8 \mathrm{M})$ and ergosterol $(400 \mu \mathrm{g} / \mathrm{mL})$ against Aspergillus spp.

\begin{tabular}{|c|c|c|c|c|c|c|}
\hline \multirow[b]{2}{*}{ Microorganisms } & \multicolumn{6}{|c|}{ MIC values $(\mu \mathrm{g} / \mathrm{mL})$} \\
\hline & $\begin{array}{l}\text { A. fumigatus } \\
\text { ATCC } 46913\end{array}$ & $\begin{array}{c}\text { A. flavus } \\
\text { ATCC } 16013\end{array}$ & $\begin{array}{l}\text { A. fumigatus } \\
\text { ATCC } 46913\end{array}$ & $\begin{array}{c}\text { A. flavus } \\
\text { ATCC } 16013\end{array}$ & $\begin{array}{l}\text { A. fumigatus } \\
\text { ATCC } 46913\end{array}$ & $\begin{array}{c}\text { A. flavus } \\
\text { ATCC } 16013\end{array}$ \\
\hline Drugs & \multicolumn{2}{|c|}{-Sterols } & \multicolumn{2}{|c|}{ +Sorbitol } & \multicolumn{2}{|c|}{ +Ergosterol } \\
\hline Cou-UNO ${ }_{2}$ & 16 & 16 & 256 & 256 & 16 & 16 \\
\hline Amphotericin B & 2 & 2 & - & - & 16 & 16 \\
\hline Fluconazole & 256 & 512 & 512 & 512 & 256 & 512 \\
\hline
\end{tabular}

Note. Cou- $\mathrm{UNO}_{2}$ : 7-hydroxy-6-nitro-2H-1-benzopyran-2-one.

(control) of the test-drugs is shown in Figure 3. In the two test concentrations $(\mathrm{MIC}$ and $\mathrm{MIC} \times 2), \mathrm{Cou}-\mathrm{NO}_{2}$ displayed significant inhibitory action for Aspergillus spp. $(P<0.05)$, as compared to the control. However, this action was shown to be less potent $(P<0.05)$ when compared with respective concentrations of Amphotericin B.

The great challenge when developing new antifungal drugs is in the similarity between fungal microorganisms cells and human cells. Thus, the desired targets for a new antifungal's action must be unique or at least sufficiently different from the host $[27,28]$. Based on this, two important fungal structures become targets for detecting antifungal drugs: the fungal cell wall and ergosterol present in the plasma membrane.

Many drugs available for clinical use interact directly with ergosterol, causing damage to the fungal cell membrane [29]. If the effects of coumarin compounds on the fungal cell are due to ergosterol binding in the membrane, one can verify if they interact directly. In the presence of exogenous ergosterol in the culture medium, decreased binding of the product to the ergosterol of the membrane occurs. Thus, the product's MIC tends to increase in the presence of exogenous ergosterol, needing a much higher concentration to interact with the fungal membrane ergosterol [16, 21].

In this study, the MIC values for both Cou- $\mathrm{NO}_{2}$ experiments, with or without exogenous ergosterol in the culture media, were identical, suggesting that the coumarin derivative tested does not act via binding to ergosterol in the plasma membrane.

To investigate the action of the coumarin derivative (Cou$\mathrm{NO}_{2}$ ) on the cell wall we carried osmotic shield testing with sorbitol; the test results are shown in Table 2. The MIC values of the Cou- $\mathrm{NO}_{2}$ increased 4-fold in the presence of sorbitol in the culture medium when compared to medium without sorbitol. This suggests that $\mathrm{Cou}-\mathrm{NO}_{2}$ acts on the fungal cell wall structure. This is the first report of such activity on filamentous fungi.

According to Widodo et al. [30] coumarin acts by forming pores in the cell wall, with consequent release of cytoplasmic contents and cell death, confirming the results found in this 
TABLE 3: MIC values of antifungals in the absence and presence of coumarin derivative, 7-hydroxy-6-nitro-2H-1-benzopyran-2-one, MIC/8, against Aspergillus spp.

\begin{tabular}{|c|c|c|c|c|}
\hline \multirow[b]{2}{*}{ Drugs } & \multicolumn{2}{|c|}{ MIC alone } & \multicolumn{2}{|c|}{ Combined MIC $\left(\mathrm{Cou}-\mathrm{NO}_{2}\right)$} \\
\hline & $\begin{array}{l}\text { A. fumigatus } \\
\text { ATCC } 46913\end{array}$ & $\begin{array}{c}\text { A. flavus } \\
\text { ATCC } 16013\end{array}$ & $\begin{array}{l}\text { A. fumigatus } \\
\text { ATCC } 46913\end{array}$ & $\begin{array}{c}\text { A. flavus } \\
\text { ATCC } 16013\end{array}$ \\
\hline Amphotericin B & 2 & 2 & 2 & 2 \\
\hline Fluconazole & 256 & 256 & 128 & 128 \\
\hline Itraconazole & 128 & 128 & 32 & 128 \\
\hline Voriconazole & 4 & 2 & 0,5 & 1 \\
\hline
\end{tabular}

TABLE 4: MIC of Antifungal drugs and effect of combination with coumarin derivative, 7-hydroxy-6-nitro-2H-1-benzopyran-2one (Cou- $\left.\mathrm{UNO}_{2}\right)$, against A. flavus, ATCC 16013.

\begin{tabular}{|c|c|c|}
\hline Antifungal $+\mathrm{Cou}-\mathrm{UNO}_{2}$ & $\begin{array}{c}\mathrm{MIC} \\
(\mu \mathrm{g} / \mathrm{mL})\end{array}$ & $\begin{array}{c}\text { FIC index } \\
\text { (Type of interaction) }\end{array}$ \\
\hline $\mathrm{Cou}-\mathrm{UNO}_{2}$ & 16 & \\
\hline Amphotericin B & 2 & \\
\hline Fluconazole & 256 & \\
\hline Itraconazole & 128 & \\
\hline Voriconazole & 4 & \\
\hline Cou- $\mathrm{UNO}_{2} /$ Amphotericin B & $16 / 2$ & 2 (Indifferent) \\
\hline Cou-UNO $2 /$ Fluconazole & $16 / 256$ & 2 (Indifferent) \\
\hline Cou-UNO $2 /$ Itraconazole & $8 / 32$ & 0,75 (Additivity) \\
\hline Cou-UNO ${ }_{2} /$ Voriconazole & $8 / 1$ & 0,75 (Additivity) \\
\hline
\end{tabular}

Note. Cou-UNO 2 : 7-hydroxy-6-nitro-2H-1-benzopyran-2-one. FIC: fractional inhibitory concentration. MIC: minimal inhibitory concentration.

study. However, other studies show that coumarins alter the morphology of the fungal mitochondrial cell and induce apoptosis [31, 32].

In addition to their inherent antimicrobial properties, natural products and their derivatives may alter the effects of standard antifungal agents (those used in clinical practice). The use of two or more antifungal combinations can lead to a reduction in the required drug dosages and decrease the normally produced adverse event profile $[33,34]$.

The addition of coumarin derivative, 7-hydroxy-6-nitro$2 \mathrm{H}$-1-benzopyran-2-one, $\left(\mathrm{Cou}-\mathrm{NO}_{2}\right)$ to the growth medium at a subinhibitory concentration of $2 \mu \mathrm{g} / \mathrm{mL}$ (MIC/8) resulted in a decreased MIC for Fluconazole $256 \mathrm{mg} / \mathrm{mL}$ to $128 \mathrm{mg} / \mathrm{mL}$ in both A. flavus and A. fumigatus. The MIC of Voriconazole decreased for A. fumigatus from $4 \mu \mathrm{g} / \mathrm{mL}$ to $0.5 \mu \mathrm{g} / \mathrm{mL}$ and for A. flavus from $2 \mu \mathrm{g} / \mathrm{mL}$ to $1 \mu \mathrm{g} / \mathrm{mL}$ for the respective species. Also, the MIC of Itraconazole decreased from $128 \mu \mathrm{g} / \mathrm{mL}$ to $32 \mu \mathrm{g} / \mathrm{mL}$, yet only for A. fumigatus, as demonstrated in Table 4 . There was, however, no significant modulatory effect on the MIC of Amphotericin B (Table 3).

In Tables 4 and 5, the results are observed for combinations of the coumarin derivative 7-hydroxy-6-nitro$2 \mathrm{H}-1$-benzopyran-2-one $\left(\mathrm{Cou}-\mathrm{NO}_{2}\right)$ with antifungal agents (Amphotericin $\mathrm{B}$ and azole derivatives) against $A$. fumigatus ATCC 46913 and A. flavus ATCC 16013. Additive effects were observed for the combinations of Cou- $\mathrm{NO}_{2}$ with Itraconazole
TABLE 5: MIC of antifungal drugs and effect of combination with coumarin derivative, 7-hydroxy-6-nitro-2H-1-benzopyran-2one (Cou-1), against A. fumigatus, ATCC 46913.

\begin{tabular}{|c|c|c|}
\hline Antifungal $+\mathrm{Cou}-\mathrm{UNO}_{2}$ & $\begin{array}{c}\text { MIC } \\
(\mu \mathrm{g} / \mathrm{mL})\end{array}$ & $\begin{array}{c}\text { FIC index } \\
\text { (Type of interaction) }\end{array}$ \\
\hline Cou- $\mathrm{UNO}_{2}$ & 16 & \\
\hline Amphotericin B & 2 & \\
\hline Flucanozole & 256 & \\
\hline Itraconazole & 128 & \\
\hline Voriconazole & 2 & \\
\hline Cou- $\mathrm{UNO}_{2} /$ Amphotericin B & $16 / 2$ & 2 (indifferent) \\
\hline Cou-UNO ${ }_{2} /$ Flucanozole & $16 / 256$ & 2 (indifferent) \\
\hline Cou-UNO $2 /$ Itraconazole & $4 / 64$ & 0,75 (additivity) \\
\hline Cou- $\mathrm{UNO}_{2} /$ Voriconazole & $8 / 0,5$ & 0,5 (additivity) \\
\hline
\end{tabular}

Note. Cou- $\mathrm{UNO}_{2}$ : 7-hydroxy-6-nitro-2H-1-benzopyran-2-one. FIC: fractional inhibitory concentration. MIC: minimal inhibitory concentration.

and Voriconazole, resulting in a fractional inhibitory concentration (FIC) index of equal to 0.75 against both respective species tested. However, the combination of the Cou- $\mathrm{NO}_{2}$ and Amphotericin B and Fluconazole showed CIF index of 2 and 2 , respectively, for each species tested.

According to these results, coumarin derivatives positively modulated the in vitro action of the azole derivatives, and the combinations with Voriconazole and Itraconazole obtained additive effects, suggesting future pharmacological use as an adjuvant for these drugs.

Several reports have been made concerning different antifungal combinations assayed in vitro and applied in the clinic [33, 35-37], and with other plant derivatives [10], but combinations of a coumarin derivative with synthetic drugs against Aspergillus spp. are reported here for the first time.

\section{Conclusion}

Based on these results, the present study demonstrates that 7-hydroxy-6-nitro-2 H-1-benzopyran-2-one $\left(\mathrm{Cou}-\mathrm{NO}_{2}\right)$ is capable of inhibiting both the mycelial growth and germination of conidia for the Aspergillus species tested, thus interfering in its virulence. The results also suggest that the action of coumarin derivatives affects the structure of the fungal cell wall. At subinhibitory concentration, $\mathrm{Cou}-\mathrm{NO}_{2}$ enhanced the in vitro effects of azoles. In addition, in combination with the azoles (Voriconazole and Itraconazole) Cou- $\mathrm{NO}_{2}$ displays an 
additive effect. Thus, our studies support the potential use of 7-hydroxy-6-nitro-2H-1-benzopyran-2-one as an antifungal agent against Aspergillus species.

\section{Conflict of Interests}

The authors declare that there is no conflict of interests regarding the publication of this paper.

\section{Authors' Contribution}

The authors Felipe Queiroga Sarmento Guerra, Rodrigo Santos Aquino de Araújo, Janiere Pereira de Sousa, Fillipe de Oliveira Lima, Francisco J. B. Mendonça-Junior, José M. Barbosa-Filho, and Edeltrudes de Oliveira Lima are responsible for drafting the paper and listed below are the individual contributions of each author to the paper. Felipe Queiroga Sarmento Guerra participated in the project design, collection and analysis of data, drafting the paper, and critical revision of the intellectual content. Janiere Pereira de Sousa participated in data collection, data analysis, and revision of the paper. Fillipe de Oliveira Lima participated in data collection, data analysis, and revision of the paper. Rodrigo Santos Aquino de Araújo participated in coumarin synthesis, data analysis, and revision of the paper. Francisco J. B. Mendonça-Junior participated in coumarin synthesis, data analysis, and revision of the paper. José M. BarbosaFilho participated in coumarin synthesis, data analysis, and revision of the paper. Edeltrudes de Oliveira Lima guided all stages of the work and participated in both review and drafting of the project and the paper, including final approval of the version to be published.

\section{Acknowledgments}

The authors are grateful to CAPES (Coordenação de Aperfeiçoamento Pessoal de Nível Superior) and Federal University of Paraíba (UFPB) for financial support and to David Harding who edited the English version.

\section{References}

[1] M. D. Richardson, "Changing patterns and trends in systemic fungal infections," Journal of Antimicrobial Chemotherapy, vol. 56, no. 1, pp. 5-11, 2005.

[2] A. Espinel-Ingroff, "Novel antifungal agents, targets or therapeutic strategies for the treatment of invasive fungal diseases: a review of the literature (2005-2009)," Revista Iberoamericana de Micología, vol. 26, no. 1, pp. 15-22, 2009.

[3] T. J. Walsh, E. J. Anaissie, D. W. Denning et al., "Treatment of aspergillosis: clinical practice guidelines of the infectious diseases society of America," Clinical Infectious Diseases, vol. 46, no. 3, pp. 327-360, 2008.

[4] D. S. Amorim, L. Maria-Moreira, C. D. R. Amorim et al., "Infecções por Aspergillus spp: aspectos gerais," Pulmão RJ, vol. 13, pp. 111-118, 2004.

[5] M. H. Miceli and S. A. Lee, "Emerging moulds: epidemiological trends and antifungal resistance," Mycoses, vol. 54, no. 6, pp. e666-e678, 2011.
[6] F. Maggi, L. Barboni, G. Caprioli et al., "HPLC quantification of coumarin in bastard balm (Melittis melissophyllum L., Lamiaceae)," Fitoterapia, vol. 82, no. 8, pp. 1215-1221, 2011.

[7] N. Hamdi, A. S. Al-Ayed, R. B. Said, and A. Fabienne, "Synthesis and characterization of new thiazolidinones containing coumarin moieties and their antibacterial and antioxidant activities," Molecules, vol. 17, no. 8, pp. 9321-9334, 2012.

[8] S. Johann, B. G. Mendes, F. C. Missau, M. A. de Resende, and M. G. Pizzolatti, "Antifungal activity of five species of Polygala," Brazilian Journal of Microbiology, vol. 42, no. 3, pp. 1065-1075, 2011.

[9] R. S. A. de Araujo, F. Q. S. Guerra, E. D. O. Lima et al., "Synthesis, structure-activity relationships (SAR) and in silico studies of coumarin derivatives with antifungal activity," International Journal of Molecular Sciences, vol. 14, no. 1, pp. 1293-1309, 2013.

[10] M. S. A. Khan and I. Ahmad, "Antifungal activity of essential oils and their synergy with fluconazole against drug-resistant strains of Aspergillus fumigatus and Trichophyton rubrum," Applied Microbiology and Biotechnology, vol. 90, no. 3, pp. 1083-1094, 2011.

[11] R. Cleeland and E. Squires, "Evalution of new antimicrobials in vitro and in experimental animal infections," in Antibiotics in Laboratory Medicine, V. Lorian, Ed., pp. 739-786, Lippincott Williams \& Wilkins, Baltimore, Md, USA, 3rd edition, 1991.

[12] F. Hadacek and H. Greger, "Testing of antifungal natural products: methodologies, comparability of results and assay choice," Phytochemical Analysis, vol. 11, no. 3, pp. 137-147, 2000.

[13] F. Sahin, M. Güllüce, D. Daferera et al., "Biological activities of the essential oils and methanol extract of Origanum vulgare ssp. vulgare in the Eastern Anatolia region of Turkey," Food Control, vol. 15, no. 7, pp. 549-557, 2004.

[14] F. Hadacek and H. Greger, "Testing of antifungal natural products: methodologies, comparability of results and assay choice," Phytochemical Analysis, vol. 11, no. 3, pp. 137-147, 2000.

[15] R. Cleeland and E. Squires, "Evaluation of new antimicrobials in vitro and in experimental animal infection," in Antibiotics in Laboratory Medicine, Williams \& Wilkins, New York, NY, USA, 1991.

[16] N. Sharma and A. Tripathi, "Effects of Citrus sinensis (L.) Osbeck epicarp essential oil on growth and morphogenesis of Aspergillus niger (L.) Van Tieghem," Microbiology Research, vol. 163, no. 3, pp. 337-344, 2006.

[17] F. de Oliveira Pereira, J. M. Mendes, and E. de Oliveira Lima, "Investigation on mechanism of antifungal activity of eugenol against Trichophyton rubrum," Medical Mycology, vol. 51, no. 5, pp. 507-513, 2013.

[18] B. K. Rana, U. P. Singh, and V. Taneja, "Antifungal activity and kinetics of inhibition by essential oil isolated from leaves of Aegle marmelos," Journal of Ethnopharmacology, vol. 57, no. 1, pp. 29-34, 1997.

[19] T. Liu, Q. Zhang, L. Wang et al., "The use of global transcriptional analysis to reveal the biological and cellular events involved in distinct development phases of Trichophyton rubrum conidial germination," BMC Genomics, vol. 8, article 100, 2007.

[20] D. J. Frost, K. D. Brandt, D. Cugier, and R. Goldman, "A whole-cell Candida albicans assay for the detection of inhibitors towards fungal cell wall synthesis and assembly," Journal of Antibiotics, vol. 48, no. 4, pp. 306-310, 1995.

[21] M. C. A. Leite, A. P. B. Bezerra, J. P. Sousa, F. Q. Guerra, and E. d. Lima, "Evaluation of antifungal activity and mechanism 
of action of citral against Candida albicans," Evidence-Based Complementary and Alternative Medicine, vol. 2014, Article ID 378280, 9 pages, 2014.

[22] A. Escalante, M. Gattuso, P. Pérez, and S. Zacchino, "Evidence for the mechanism of action of the antifungal phytolaccoside B isolated from Phytolacca tetramera Hauman," Journal of Natural Products, vol. 71, no. 10, pp. 1720-1725, 2008.

[23] G. M. Eliopoulos and R. C. Moellering, "Antimicrobial combinations," in Antibiotics in Laboratory Medicine, V. Lorian, Ed., pp. 434-441, Lippincott Williams \& Wilkins, Baltimore, Md, USA, 1991.

[24] F. Q. S. Guerra, J. M. Mendes, J. P. D. Sousa et al., "Increasing antibiotic activity against a multidrug-resistant Acinetobacter spp by essential oils of Citrus limon and Cinnamomum zeylanicum," Natural Product Research, vol. 26, no. 23, pp. 2235-2238, 2012.

[25] H. D. M. Coutinho, J. G. M. Costa, E. O. Lima, V. S. Falcão-Silva, and J. P. Siqueira Jr., "Enhancement of the antibiotic activity against a multiresistant Escherichia coli by Mentha arvensis L. and chlorpromazine," Chemotherapy, vol. 54, no. 4, pp. 328-330, 2008.

[26] S. H. Chotirmall, B. Mirkovic, G. M. Lavelle, and N. G. McElvaney, "Immunoevasive Aspergillus virulence factors," Mycopathologia, vol. 178, no. 5-6, pp. 363-370, 2014.

[27] R. L. Cihlar, C. Kellogg, and J. R. S. Broedel, "Antifungal drugs targets: discovery and selection," in Fungal Phatogenesis: Prenciples and Clinical Applications, R. A. Alderone and R. L. Cihlar, Eds., Marcel Dekker, New York, NY, USA, 2002.

[28] N. M. Martinez-Rossi, N. T. A. Perez, and A. Rossi, "Antifungal resistance mechanisms in dermathophytes," Mycopathology, vol. 166, pp. 369-383, 2008.

[29] J. M. Valgus, "What's new in antifungals?" Current Infectious Disease Reports, vol. 5, no. 1, pp. 16-21, 2003.

[30] G. P. Widodo, E. Y. Sukandar, and I. K. Adynyana, "Mechanism of action of coumarin against $C$. albicans by SEM/TEM analysis," ITB Journal Science, vol. 44A, pp. 145-151, 2012.

[31] S. M. Razavi, "Plant coumarins as allelopathic agents," International Journal of Biological Chemistry, vol. 5, no. 1, pp. 86-90, 2011.

[32] E. Kupidlowska, K. Dobrzynska, E. Parys, and A. M. Zobel, "Effect of coumarin and xanthotoxin on mitochondrial structure, oxygen uptake, and succinate dehydrogenase activity in onion root cells," Journal of Chemical Ecology, vol. 20, no. 10, pp. 2471-2480, 1994.

[33] J. A. Vazquez, "Combination antifungal therapy for mold infections: much ado about nothing?" Clinical Infectious Diseases, vol. 46, no. 12, pp. 1889-1901, 2008.

[34] R. D. Castro, Atividade antifúngica do óleo essencial de Cinnamomum zeylanicum Blume (Canela) e de sua associação com antifúngicos sintéticos sobre espécies de Candida [M.S. thesis], Federal University of Paraíba, João Pessoa, Brazil, 2010.

[35] R. E. Lewis, R. A. Prince, J. Chi, and D. P. Kontoyiannis, "Itraconazole preexposure attenuates the efficacy of subsequent amphotericin B therapy in a murine model of acute invasive pulmonary aspergillosis," Antimicrobial Agents and Chemotherapy, vol. 46, no. 10, pp. 3208-3214, 2002.

[36] L. K. Najvar, A. Cacciapuoti, S. Hernandez et al., "Activity of Posaconazole Combined with Amphotericin B against Aspergillus flavus infection in mice: comparative studies in two Laboratories," Antimicrobial Agents and Chemotherapy, vol. 48, no. 3, pp. 758-764, 2004.
[37] A. Elefanti, J. W. Mouton, P. E. Verweij, A. Tsakris, L. Zerva, and J. Meletiadis, "Amphotericin B- and voriconazole-echinocandin combinations against Aspergillus spp.: effect of serum on inhibitory and fungicidal interactions," Antimicrobial Agents and Chemotherapy, vol. 57, no. 10, pp. 4656-4663, 2013. 


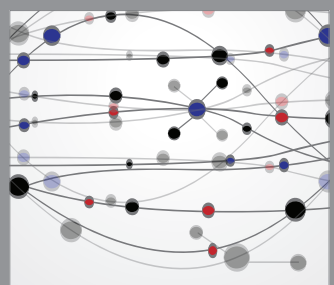

The Scientific World Journal
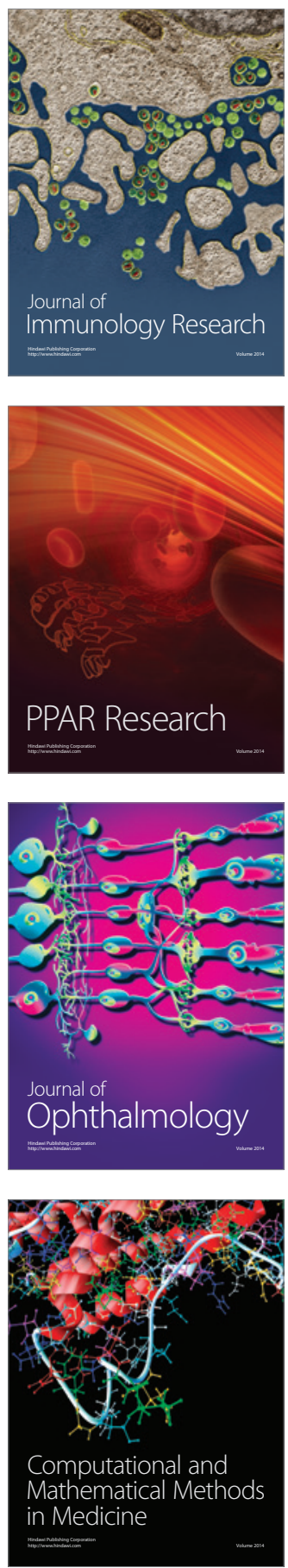

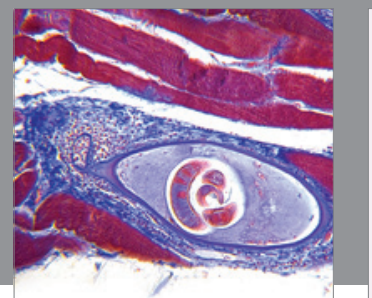

Gastroenterology

Research and Practice
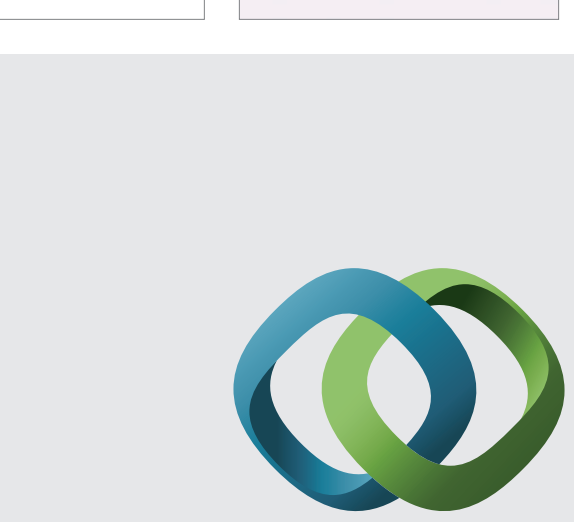

\section{Hindawi}

Submit your manuscripts at

http://www.hindawi.com
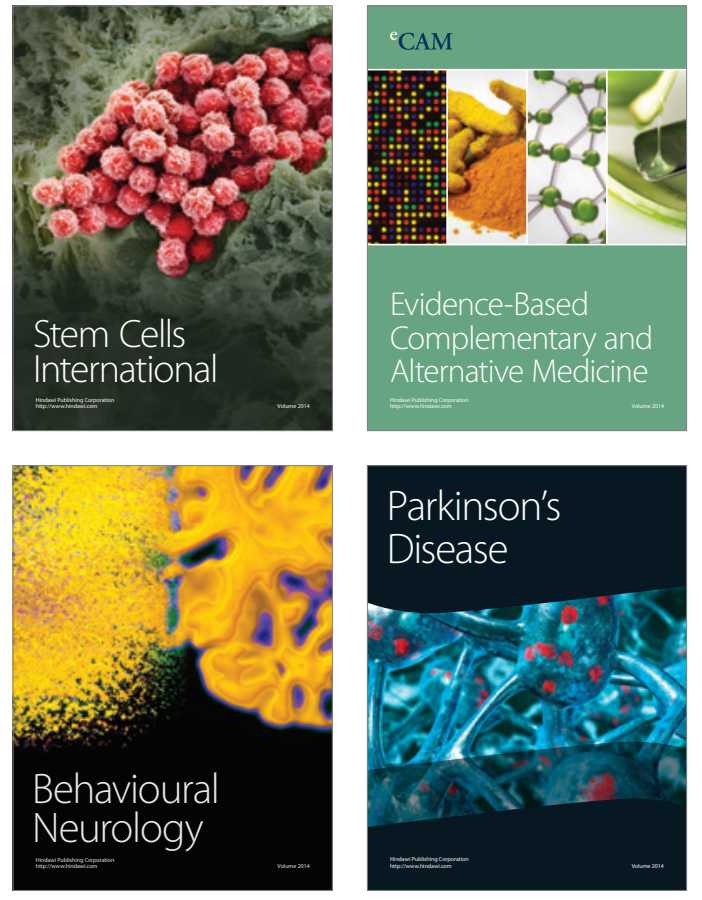
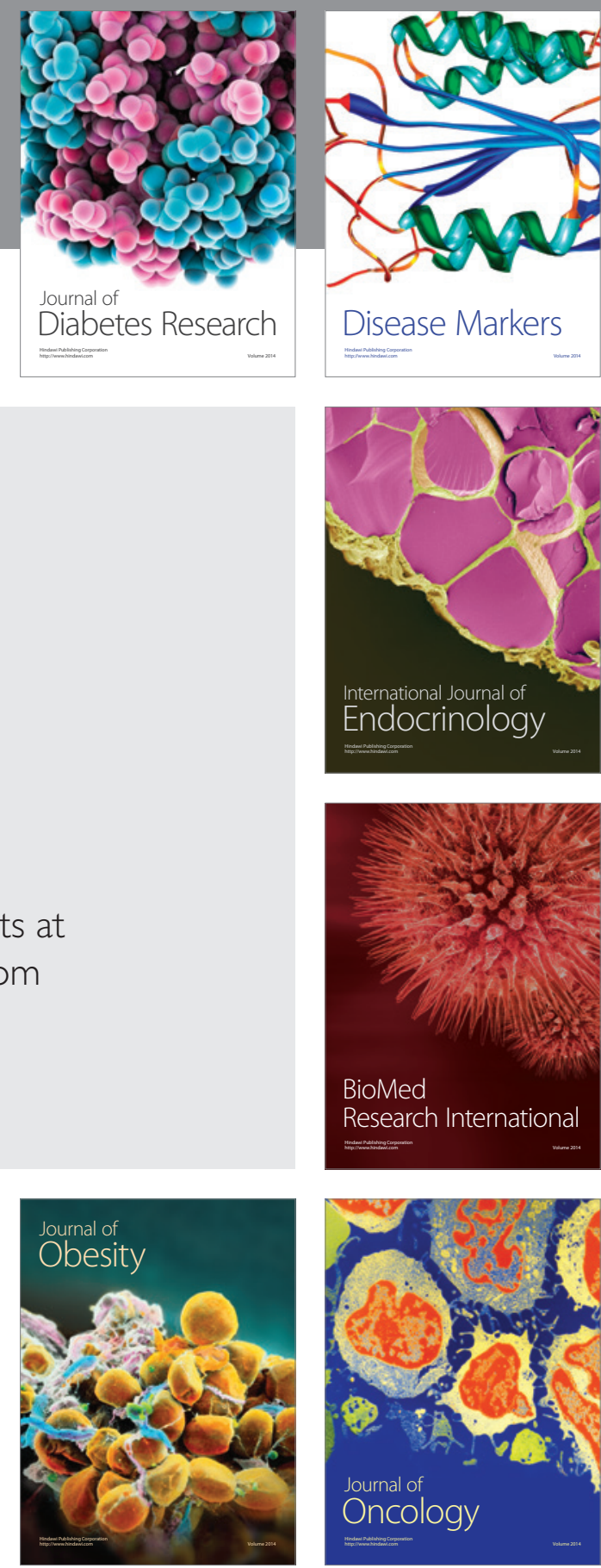

Disease Markers
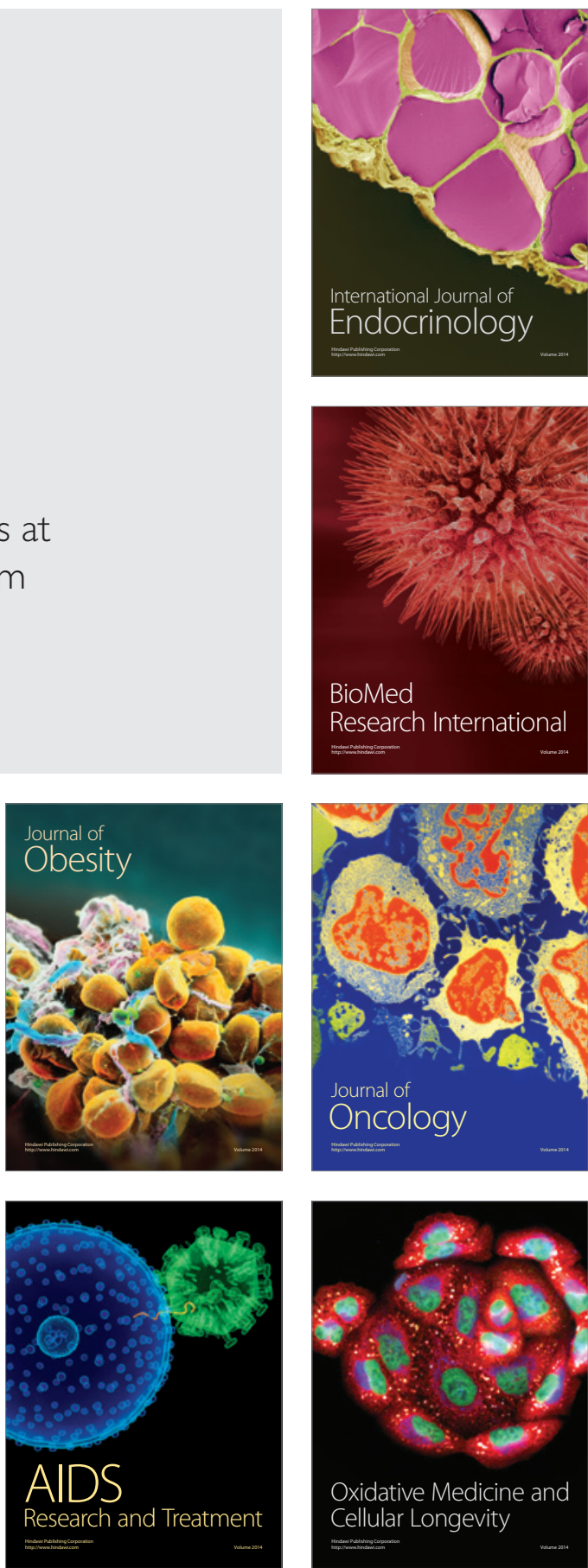